\title{
What Teachers of Academic Writing Can Learn from the Writing Center
}

\author{
Bonnie Devet \\ College of Charleston, USA
}

\begin{abstract}
For over fifty years, US writing centers have been helping students, with writing centers found in approximately $90 \%$ of American universities and colleges (Eodice 2009). Because those who direct and tutor see student writers struggling with every kind of assignment, writing centers are important resources for anyone teaching writing or writing-intensive courses.

Ironically, though, writing centers are an overlooked resource on literacy. As Eric Hobson and Muriel Harris argue, writing centers should share with those who teach writing to larger groups what writing center professionals have learned about the writing process. Based on four years of systematic research interviewing experienced writing center tutors, this article presents teachers of academic writing with valuable insights into how students misunderstand the writing process and how teachers of academic writing can improve their teaching of writing.
\end{abstract}

\section{Introduction}

For at least a half century, US writing centers have been helping students, with centers being found in approximately $90 \%$ of American universities and colleges, according to Michele Eodice, past president of the International Writing Centers Association (Eodice 2009). Because writing center tutors see writers struggling with every kind of paper, writing centers - with their wealth of knowledge about assisting students - can be an important resource for anyone teaching writing or writing intensive courses.

Ironically, though, writing centers are an overlooked resource on literacy. As Eric Hobson (1999), Muriel Harris (1995) and, more recently, Elizabeth Boquet and Neal Lerner (2008) argue, writing centers should share what they have learned about the writing process with those who teach writing to larger groups. The result, as Harris explains, is that 'writing center research will be the instrument of institutional change; writing center research will forge new paths' (2002: 75).

What better resource could there be than the student tutors (also called 'peer consultants') who work in a writing center? These 'knowledge workers', as Nancy Grimm (2008) has labeled them, are students whom classroom faculty have nominated to work in a writing center. Each day, in the trenches, these hand-picked students - often undergraduates or graduates - help all levels of students in every type of course with writing assignments as varied as term papers for history, lab reports for biology, or literary analyses for English. In doing so, student tutors have acquired a wealth of ideas about how student writers (also known as writing center 'clients') think and compose. In US colleges and universities, writing classes can, unfortunately, number twenty to thirty students, so teachers of academic writing may not have a chance to determine how individual students perceive the writing process. But writing centers, because of their unique position of 'talking in the middle' with student 'clients' (Harris 1995), sense more fully, more completely, what students view as writing problems.

So, as a writing center director, I have been asking peer consultants about their work. Over the last four years, I have surveyed thirty-three peer consultants, with a combined experience of over fifty- 
seven years working in a writing center, and I have discovered that student tutors are an unimpeachable source for providing teachers of academic writing with insights into how student writers perceive the writing process, and into how teachers can improve their teaching of academic writing. While this paper focuses on an American writing center's peer consultants and student clients, who are mostly native speakers of English, its conclusions are applicable to all students struggling with the writing process; therefore, the student tutors' insights should be fed back to classroom faculty in order that they can adjust their instructive practices.

\section{Clients' Misunderstanding of the Nature of Writing}

\section{A perfect first-draft}

One of the first problems peer consultants noted in response to the survey is that students do not always grasp the complex nature of the writing process. Many students come to the writing center expecting to produce one draft, their first, and that it will be perfect, born directly out of their heads like Athena. This perception indicates clients falsely believe that knowledge is objective, somewhere out there, waiting to be found (Faigley 1986) even though composition theorists have shown that knowledge and writing are constructed socially, with each essay's rhetorical situation shaping the writing so that writers have to adjust and balance these factors, shifting for different goals and readers. The students' misconception of the process is often hidden from classroom faculty who do not always get the opportunity to work one-to-one with students. But, in a writing center, this attitude hangs like a miasma over clients as they struggle to write. A student tutor provides advice on how to help students evolve a text so that it reflects the complex process of writing:

I ask clients what are their goals as writers. Students tell me what they want to write and show me what they have gotten down so far. I help them close the gap between what they want to say and what is already on the page (Chris Snyder $\left.{ }^{1}\right)$.

\section{Oral vs. written discourses}

While students possess ideas, it is difficult for them to express those thoughts partly because of the dissonance between the oral and written versions of language, exhibiting what US researcher Nancy Sommers has characterized as the classic signs of 'inexperienced' versus 'experienced' writers (1980). Consistently, student tutors noted that the students' speaking is more effective than their writing. One student tutor reported:

It is easier for them to tell a person about their topic, but when writing, something is lost in the translation. The meaning is lost. They get confused. They speak one way, but it looks different to them on paper (Tim Havens).

Clients of the writing center even ask tutors, 'Does it sound like what I want to say?' (Sharina Kindel). As inexperienced writers, students often are more fluid with the oral version of the language than the written, not having developed what one tutor calls 'a writing voice' (Claire Voegele), where the writer is more selective, more formal in the diction, with each sentence leading to the next. Their intention, as Sommers has noted about inexperienced writers, differs from their execution (1980: 387).

\section{Writer-based prose and lower levels of critical thinking}

Student tutors noticed that drafts brought to the writing center reflect another writing problem: students tend to write as they think, producing what researcher Linda Flower calls 'writer-based prose' (1979). As a peer consultant noted, 'One client wrote her paper as she thought of it, so she needed to go back and see where to make changes' (Alison Barbiero). So, students need help converting their essays from writer-based to reader-centered prose (Flower 1979). For this problem, a student tutor suggests, 'Have the clients read aloud. When clients do, they always ask, "Does that make sense?" showing they realize their writing is not directed to an audience' (Alison Barbiero).

As students read aloud their drafts to shift between reader-centered and writer-based discourse, they may also reveal their papers are functioning at the lower levels of Benjamin Bloom's (1965) well-

\footnotetext{
${ }^{1}$ All quotations are used with the student peer consultants' permission.
} 
known taxonomy of critical thinking. While they may possess what Bloom calls 'knowledge', 'comprehension', and 'application' (that is, they recall, understand, and use information), they may not yet perform at the higher levels of 'analysis', 'synthesis', and 'evaluation' (Bloom 1965). A student tutor characterized this problem:

Student writers state in the paper there is imagery in the short story; however, they cannot analyze how this imagery evokes emotion. When they explicate a poem, they don't talk about the interrelationship of the elements. In fact, synthesizing materials, analyzing the significance of concepts, and crafting a distinct argument of one's own frequently escape clients' attention. (Chris Snyder)

Student writers, then, may know the material about which they are writing; nonetheless, they seek the writing center's help with a vital part of the writing process - making the leap from merely listing ideas to engaging in analysis.

Formulating a thesis based on research and developing ideas independent of sources Using resources - so readily available from Google and other Internet search engines - poses another difficulty. '[Students] find researching is easy, but they do not know how to incorporate the research once it is found', reports the student tutor Chelsea Rudd. The sources so overwhelm students that they cannot discern what their thesis statement should be. A peer consultant characterizes the problem as. 'They need help with the big picture, making sure the thesis is supported. They have to see the thesis as a lighthouse for the theme of the entire essay' (Brad Marialke).

As if crafting a thesis statement were not hard enough, students also often rely too heavily on their secondary sources without supplying their own views. An experienced student tutor explained:

It is easy to fall into this trap. A critic says a Shakespearean sonnet is about death, so clients go with it even if they think the sonnet is about sorrow. It is safer to use others' ideas. They are satisfied with what others have said. This attitude occurs not just for the first-year students but at all levels (Rachel Oja).

Therefore, in the view of the writing center tutors interviewed, students need to learn to better appropriate their sources.

\section{Improving the Teaching of Writing}

Besides describing how students perceive the composing process, peer consultants are also eager to give advice to classroom faculty on how to improve the teaching of academic writing.

\section{Establishing the value of writing and explaining the purposes for assignments}

Context is everything. Without knowing the 'why' for doing a piece of writing, the work will make no sense to students, and when students do not grasp the educational value of writing, they see their writing assignments as only 'inconveniences'. In fact, during a writing center tutorial, it is not uncommon to hear clients ask student tutors, 'Why do I have to write this?' Peer consultants suggest, then, that teachers of academic writing explain why writing is seminal to learning and describe the goals for the assignment. As tutor Julie Delizza reports:

Faculty need to make clear where their priorities are. Is the purpose of the assignment to show MLA [referencing] format fluency, or is it to show an understanding of materials covered last week? Students freak out when given only minimal guidelines.

Moreover, 'In a good class, the assignment sheet has a frame of reference as to why students are doing the work' says the student tutor Brittany Kale.

\section{Using specific, accurate wording on assignment sheets}


All too often, writing center tutors and students find assignment sheets to be indefinite (Glenn and Goldthwaite 2008: 101). One peer consultant explains:

Sometimes the questions assigned are too broad, such as 'Write about women in 19th century Europe.' That could be narrowed to 'Write about Women's cultural status in 19th century Europe' (Rachel Reinke).

Another way to eliminate the vagueness is for classroom faculty to demonstrate what they want their classes to do:

A topic could be 'Discuss irony in The Great Gatsby'. Teachers of academic writing need to remind students about what they have talked about in class (like types of irony) and, then, model for the class what to discuss, such as dramatic irony or verbal irony (Tim Havens).

In this desire for clarity, faculty should define any diction which might confuse students, such as the assignment sheet that asked, 'Write a postscript to your paper'. A student tutor reported that students were confused by these directions because they did not understand the word postscript. Even diction with which classroom faculty are familiar may not always be readily understood by their students. Take the word that is the bane of many an assignment: analyze. One student tutor explained the clients' reaction:

Students do not know this word, and professors do not define it or define it differently depending on the professors. Analyze could mean, to one professor, just relate the material to the subjects we are already studying in the course or relate it to the class discussions. Or the word could mean 'not what it says but what it means' (Brittany Kale).

Although student tutors are sympathetic to the difficulties of writing adequate assignments, they are also aware, as one student consultant said, that 'professors, particularly English professors, usually have a substantial vocabulary so they may not even realize when something is a little over a student's head' (Mary Franklin Harvin). Careful word choice, then, would improve classroom faculty's assignment sheets.

\section{Giving the 'circulation' of a paper assignment}

Besides wording, peer tutors hear students complain about another vital feature on assignment sheets, what Kenneth Burke (1966) characterizes as 'circulation' - that is, providing students with the audience, the discourse style, and the medium so they know to whom they are writing. As a peer consultant explained, 'Without the full rhetorical situation, students usually end up writing for the teacher, producing prose that is deadly and dull, not reflective of the rhetorical powers most students inherently possess' (Claire Voegele). So, teachers of academic writing should specify the audience. One peer consultant provided an example from her own courses: 'It could be a book review for an informed public that reads the paper and wants to appreciate art' (Claire Voegele). As a result, students can grasp the complete rhetorical situation (Strasman 2007: 249).

\section{Establishing 'teacher immediacy'}

Writing center consultants are masters at establishing an atmosphere that is supportive, and knowing how such an atmosphere fosters students' success, consultants are particularly eager that classroom faculty also establish the same rapport with their students. Student tutors noted, however, that teachers can be so intimidating that students avoid seeking help from classroom faculty:

They don't like to go the professor's office unless the paper is already 'perfect,' for they fear the teacher will yell at them. They don't like to go to office hours because it is scarier to talk to a professor than to [peer] consultants who have already taken lots of classes just like the clients (Heather Alexander).

Classroom faculty - whether aware of it or not - sometimes lack what Communication theorists designate as 'teacher immediacy', defined by Janie Wilson as 'psychological availability' (Wilson n.d.). In other words, many writing center clients think faculty, for the most part, are not providing verbal and nonverbal signals to help student's cognitive learning (McCroskey et al. 1996: 210). These behaviors, as simple as gesturing, varying the voice, smiling, 'looking at the class while talking', 
'having a relaxed body position' (McCrosky et al. 1996: 206), often mean the difference between students' learning and not learning, or in this case, feeling as if they can approach classroom faculty for help.

To eliminate this fear factor, a writing center tutor suggests that on the first day of class, before launching into the syllabus, teachers of academic writing could use the typical writing center methodology for easing students into their work with a paper: be open and ask questions of students (Joanne Cinense). Perhaps another way to develop teacher immediacy, as one peer consultant suggested, would be to use the writer's workshop methods so successful in creative writing, with classes sitting in a circle, each reading and critiquing the papers so teachers seem more approachable (Joelle Pettus). Eliminating the fear factor, then, could improve teacher-student rapport about writing.

\section{Conclusion}

Students arriving at universities and colleges enter new worlds, and, as such, they have to discover for themselves what the experience will be like (Bartholomae 1985). Part of this discovery is to learn about the nature of the writing process, throwing off misconceptions and embracing writing for the educational enterprise it is designed to be. Peer consultants, working so hard in writing centers day after day, have seen first hand how these students view academic writing, noting the roadblocks that arise, roadblocks which classroom faculty, who see students with different eyes, may never realize even exist. So, as Marilyn Cooper argues, peer writing tutors can be

agents of change in writing pedagogy, helping teachers create better assignments, letting teachers know what students are having trouble with. As intellectuals, tutors contribute to the endeavor of helping students learn about writing and the endeavor of creating useful knowledge about writing (2008: 59).

These student workers can tell teachers of academic writing or writing intensive courses about students' perceptions about writing, information that teachers should know about the writing process and the teaching of writing.

It could, of course, be objected that the content as well as the method for teaching reflect cultural values (Donahue 2009); however, what these American writing tutors have observed is not tied to any one cultural act of writing. They are describing what a diversity of writers - no matter the culture - feel and fear. The difficulties and the challenges of writing know no national boundaries.

Naturally, with the academic hierarchy inherent at colleges and universities, it would also be all too easy to dismiss the consultants' observations and advice simply as comments from mere student workers. Yet, who knows better about student writers than students who help other students in writing centers? In writing centers - neutral places or what student tutors call 'judgment-free zones' - student writers are going to tell the consultants what teachers of academic writing would never hear, making writing centers important sites for researching the teaching of writing and generating for classroom faculty knowledge from the students' perspectives. 


\section{References}

Bartholomae, D. (1985) 'Inventing the University'. in When a Writer Can't Write: Studies in Writer's Block and Other Composing Process Problems. ed. by Rose, M. New York: Guilford, 273285

Bloom, B. S. (1965) Taxonomy of Educational Objectives: The Classification of Educational Goals. New York: David McKay Company

Boquet, E. and Lerner, N. (2008) 'After "The Idea of a Writing Center'". College English 71 (2), 170189

Burke, K. (1966) Language as Symbolic Action. Berkeley, CA.: University of California Press

Cooper, M. (2008) 'Really Useful Knowledge: A Cultural Studies Agenda for Writing Centers'. in St. Martin's Sourcebook for Writing Tutors. 3rd edn. ed. by Murphy, C. and Sherwood, S. Boston: Bedford/St. Martin's, 53-66

Donahue, C. (2009) 'The Lycée-to-University Progression'. The Norton Book of Composition Studies. ed. by Miller, S. New York: Norton, 1544-1582

Eodice, M. (2009) Seeking Information [email] to author [18 October 2009]

Faigley, L. (1986) 'Competing Theories of Process: A Critique and a Proposal'. College English 48 (6), $527-542$

Flower, L. A. (1979) 'Writer-based Prose: A Cognitive Basis for Problem Solving in Writing' College English 41, 19-37

Glenn, C. and. Goldthwaite, M.A. (2008) The St. Martin's Guide to Teaching Writing. 6th edn. Boston: Bedford/St. Martin's

Grimm, N. (2008) Keynote Address. 'International Writing Center/National Conference on Peer Tutoring in Writing'. held 30 October - 1 November 2008 in Las Vegas, Nevada

Harris, M. (1995) 'Talking in the Middle: Why Writers Need Writing Tutors'. College English 57, 27-42

Harris, M. (2002) 'Writing Center Administration: Making Local, Institutional Knowledge in Our Writing Centers'. in Writing Center Research Extending the Conversation. ed. by Gillespie, P., Gillam, A., Falls Brown, L. and Stay, B. Mahwah, New Jersey: Erlbaum, 75-89

Hobson, E. (1999) Charting New Directions in Writing Center Research. 'Conference on College Composition and Communication'. held March 1999 at the Atlanta Hilton, Atlanta, Georgia

McCroskey, J. C., Sallinen, A., Fayer, J. M., Richmond, V. P. and Barraclough, R. A. (1996) 'Nonverbal Immediacy and Cognitive Learning: A Cross-Cultural Investigation'. Communication Education 45, 200-211

Sommers, N. (1980) 'Revision Strategies of Student Writers and Experienced Adult Writers'. College Composition and Communication 31, 378-388

Strasman, K. (2007) 'Assignments by Design'. Teaching English in the Two-Year College 34 (2), 248-263

Wilson, J. Promoting Peaceful Classroom Teacher Immediancy [sic] [online] available from $<$ http://www.webster.edu/ woolflm/PPCteacherimmed.html> [February 2009] 